\title{
GAPIT THEATRE: NeW JAVANESE PLAYS ON TRADITION
}

\author{
G. G. Weix
}

"People's literature as a particular mode appropriate to the present is something most developed countries have no call for."

Nadine Gordimer 1992

\section{Recent National Indonesian Theatre}

The first national Indonesian Theatre Festival was scheduled originally for Ujungpandang in 1992, to be hosted together with an Art Show and Conference. Due to technical difficulties the event was delayed and rescheduled to be held at the Javanese Cultural Center (Taman Budaya Jawa) just northeast of Surakarta from July 17-22, 1993. It consisted of a week-long series of performances, panel discussions, and workshops organized by a committee of dedicated and extraordinarily energetic artists, intellectuals, teachers, actors and musicians. Many of the planners and participants were affiliated with the AKSI: Akademi Karawitan Seni Indonesia (Indonesian Performing Arts Academy) in Surakarta. (The AKSI has since changed its name and become the STSI: Sekolah Tinggi Seni Indonesia [Indonesian Art Institute]).

The events were well attended; the number of performers participating exceeded expectations, as did audience attendence, which reached from several hundred to over a thousand each night. Many of the participants who were given ten tickets to distribute found themselves asking the committee for additional entrance passes. Fourteen troupes performed to large audiences which were made up of both festival participants and neighborhood residents who drifted in to watch the outdoor stage productions. Spectators were seated at both indoor and outdoor stages from the early hours after dawn until late into the evening. Theatre troupes in attendance represented the full span of Indonesia's archipelago; although several well-known acting troupes came from the larger cities in Java, Surabaya, Surakarta, Yogyakarta and Jakarta, regional troupes also arrived by bus and by plane from Northern Sumatra, Lampung, Padang, Mataram, Samarinda, Makassar and Jayapura. ${ }^{1}$

\footnotetext{
1 Buku Panduan Pertemuan Teater Indonesia 1993, Surakarta, July 17-22, 1993. Theater groups included: Teater Alam Bengkulu, Bengkel Aktor Mataram, Bengkel Muda Surabaya, Teater RSPD Tegal, Teater Padang, Teater
} 
All the dramas were performed in Indonesian with one exception: the performance entitled Tuk (Spring), written by Bambang Widoyo S. P., a young playwright whose work is performed by the local Solonese troupe called Gapit Theatre. Widoyo writes dialogue and stage directions almost entirely in Javanese and his plays are carefully scripted to be performed with a full gamelan orchestra accompaniment. ${ }^{2}$ Indonesian journalists and critics have not proven resistant to the playwright's innovative use of vernacular traditions; in fact, they generally praise Gapit Theatre as a "new" form of national theatre and also claim it as representive of regional Javanese drama. In numerous reviews in national newspapers and magazines such as Kompas, Suara Merdeka, Sinar Harapan, Kedaulatan Rakyat and Tempo, critics compare Gapit Theatre to the older urban drama, ketoprak, since scripts are written exclusively in "low" Javanese and the story lines focus on the lives of urban neighborhood residents. What is it about Gapit performances which strikes Indonesian audiences and critics as "new?" How do we evaluate this claim that national drama is being regenerated through these provincial performances of "Javanese theatre"?

\section{Javanese Performing Arts}

Many genres of performing arts popular on Java could qualify as "Javanese." Wayang kulit, shadow puppet plays, and wayang wong, human drama based on the shadow puppet form, are the most obvious examples, although the staged comedy skits ludruk and ketoprak also come to mind. Inside the extraordinarily rich multilingual and intertextual tradition of stage performances in different parts of Java throughout the colonial and modern eras, such genres have been constantly reinvigorated and transposed to new settings; for example, the way in which the Melayu sandiwara influenced the mestizo theatre, Komedie Stambul, in the early part of the twentieth century shows how intertextuality can enrich indigenous art forms. ${ }^{3}$

For Indonesians to identify a particular genre of theatre as "Javanese" suggests that they are working within a postmodern context where it is understood that contemporary genres often cite prior forms. Through citation, provincial or regional (daerah) drama can refer to prior local forms, but also transcend its locale and thus become prominent as part of a national arts scene. In an unusual and important sense, Gapit Theatre represents "Java" through a bold and consistent scripting in regional languages. Ariel Heryanto remarks,

Gapit Theatre is not just unique modern art, and more especially [it is not just] a theatre group which works in a regional tongue. To portray Gapit Theatre as a theatre group in which players speak Javanese misses the mark (meleset). How diverse aims about class, gender and descent become realistic depends on composing the parts and elements from the regional language and culture called "Java."

Pilar Lima-Jayapura, Teater Makassar, Teater Gidig Gidig Surakarta, Grup Bangsawan Simpaian, Sumut, D.K. Samarinda, Teater Aquila, Teater Gandrik, and Forum Teater Lampung.

2 "Menggunakan sepenuhnya medium bahasa Jawa produksi Teater Gapit yang kelima ini kian menemukan bentuk keseniannya yang paling tepat, drama [berbahasa] Jawa." [Making full use of Javanese language as a medium, the fifth production of Gapit Theatre has achieved an apt artistic form: dramas in spoken/that speak Javanese.] Ardus Siwega, "Bahasa Jawa dengan Napas Indonesia," Kompas, November 9, 1983, p. 6.

3 Bronia Kornhauser, "In Defense of Kroncong," Studies in Indonesian Music, ed. Margaret J. Kartomi (Clayton, Victoria: Center of Southeast Asian Studies, Monash University, 1978).

4 "Teater Gapit bukan satu-satunya kesenian modern dan lebih khusus lagi grup teater yang berkreasi dalam bahasa daerah. Tapi menggambarkan Teater Gapit sekadar sebagai grup teater berbahasa Jasa adalah gambaran yang sangat meleset. Sebagaimana halnya ada berbagai aneka realitas dan citra tentang kelas, jenis kelamin dan 
To call Gapit "Javanese theater" implies in one sense that it presents a subaltern's portrait of Java, as it portrays the social world of the relatively powerless (wong cilik). Since James Peacock's study of ludruk, street theatre as an expression of popular culture and urban proletariat life in the 1960s, observers of Indonesian social life have noted how drama enacts and transforms cultural conventions in different historical eras. Peacock describes ludruk as kasar (crude) theatre, which gained popularity in East Java along with ketoprak, invented in the 1920s. Both sorts of dramatic performances are accompanied by gamelan, with most dialogue and audience responses scripted in Javanese. According to those sources Peacock interviewed in the early 1960s, ludruk and related stage comedy skits are contrasted in cultural terms with wayang, shadow plays, in the same way as kasar is opposed to alus, refinement. Whereas wayang epitomizes Javanese arts, ludruk is characterized as "... a rather shabby and garish spectacle." 5

This broader relationship between drama and cultural values in contemporary Java has been well studied by Barbara Hatley. ${ }^{6}$ Hatley shows that theatre troupes can articulate not only symbolic values, but also changing norms for class and gender, as demonstrated by the new roles that became available for women in ketoprak in the $1980 \mathrm{s.}^{7}$ In discovering similar tensions in a related dramatic genre, Srimulat, James Siegel shows how the Solonese theatre inscribes a broader relationship between traditional Javanese culture and the new or foreign element itself; the outlines of this confrontation can be traced by following audience response to the character of Mrs. Dracula. ${ }^{8}$ Analyzing these trends as a "new tradition," Ellen Rafferty examines themes in Putu Wijaya's scripts which also incorporate the odd or strange into familiar narratives and structures. ${ }^{9}$

In this brief essay I will analyze the particular strengths of the Gapit Theatre troupe in order to discover why it has been identified as "new Javanese theatre." In doing so I will interpret dramatic genres not only as cultural productions, but also as discursive events intertwining historical and personal experience. In some sense the plays of Gapit Theatre displace earlier genres of stage performance, particularly wayang wong, in popularity, even as they offer a retrospective portrait of Javanese society and its expressive artistic genres. ${ }^{10}$

\footnotetext{
keturunan yang tertindas, ada berbagai rerealitas dan elemen dari bahasa/budaya daerah yang disebut 'Jawa'" Ariel Heryanto, "Ideologi dan Estetika," Suara Pembaruan, January 27, 1985.

5 See James L. Peacock, Rites of Modernization: Symbolic and Social Aspects of Indonesian Proletarian Drama (Chicago: University of Chicago Press, 1968).

${ }^{6}$ See Barbara Hatley, "Wayang and Ludruk: Polarities in Java," The Drama Review 15/3: 88-101.

7 See Ward Keeler, "Speaking of Gender in Java," and Barbara Hatley, "Theatrical Imagery and Gender Ideology," Power and Difference: Gender in Island Southeast Asia, eds. Shelly Errington, Jane Atkinson. (Stanford: Stanford University Press, 1990) pp. 127-152, 177-208.

${ }^{8}$ James T. Siegel, Solo in the New Order: Language and Hierarchy in an Indonesian City (Princeton: Princeton University Press, 1986). See especially chapter four. Analyzing the significance of theater in the New Order era, Siegel shows that language takes on a force of its own which is discernable in the theatrical production through its impact on the bodies of actors (pp. 93-94) and in the identification of the audience with particular sounds (pp. 96-97). On Sri Mulat, see also Saya Shiraishi,"Silahkan Masuk, Silahkan Duduk: Reflections on a Sitting Room in Java," Indonesia 41 (1986):89-130.

9 Ellen Rafferty,"The New Tradition of Putu Wijaya," Indonesia 49 (April 1990): 103-116.

10 Alan Feinstein has argued specifically that Gapit Theatre scripts and performances confront New Order statesponsored representations of Javanese culture and artistic traditions as primarily alus, refined. In a forthcoming article written independently of this one, he provides a synopsis of Bambang Widoyo's scripts to date, and discusses the implications of Gapit Theatre's scripts as they defy reification of Javanese arts as inordinately refined. See Alan Feinstein (forthcoming), "Modern Javanese Theatre and the Politics of Culture; A Case Study
} 
Gapit Theatre's reputation for novelty has actually been enhanced by Indonesian critics who regularly compare it with a rough older genre, ketoprak, which most people would not expect contemporary playwrights to use as a source. Although Gapit plays do resemble ketoprak, the scripts clearly rely upon the wider repetoire of traditional wayang and wayang kulit performances for their broad appeal to Javanese audiences. The playwright, Bambang Widoyo, transposes specific elements from shadow plays into modern stage plays, in particular the internal elements of speech levels in Javanese. One of his characters, Bedor, in the play Leng (Ant's Nest) parodies a stock character of the servant-clowns, whose humorous commentaries are typically delivered as asides in vernacular "low "Javanese and serve to restate many of the narratives delivered in high Javanese by more refined, princely characters. Critics recognize that the idiomatic Javanese in Gapit scripts derives from a broad array of traditional genres. ${ }^{11}$ Since the playwright often draws on specific legends and mythic narratives, he assumes the spectators will be familiar with the characters from the wayang tradition. Hari Utomo, one critic, notes that contemporary audiences may lack detailed knowledge of shadow plays and therefore find wayang philosophical references burdensome in a contemporary Gapit production. ${ }^{12}$ However, Gapit theatre continues to win an enthusiastic response from both artistic and popular audiences, indicating that while the critics may see resemblances to ketoprak, the audiences enjoy the recollection of wayang in subject matter and tone. ${ }^{13}$

These dramas are finally most distinctive in their exclusive use of the "low" Javanese idiom, which distinguishes them from traditional wayang performances in which a full range of Javanese speech levels as well as archaic language have always flourished. ${ }^{14}$ Speaking exclusively "low" Javanese, the characters of Widoyo's plays constantly recreate a vantage from which to appreciate Javanese performing arts, thus experimenting in intertextual exercises which are accepted as characteristic of contemporary Indonesian theatre. This intertextuality is a clue to why critics have identified Widoyo's plays as "Javanese theater" and "national theatre," for the plays simultaneously extend older genres even as they improvise a reflexive stance toward the living vernacular "Java" for the Indonesian audience. ${ }^{15}$

Thus Gapit Theatre troupe's performances have been praised not only for their quality, but for creating a new model for Javanese arts (gagrag anyar, atau model baru untuk sastra

of Teater Gapit." I would like to thank him for sharing his article and for his comments on prior versions of this essay.

11 "Solo sendiri memberikan nuansa idiom2 kejawaan yang kaya. Warisan khasanah kebudayaan tradisi, seperti wayang, kethoprak, wayang orang dan sebagainya merupakan sumber ide dan sumber semangat yang tak ada habis2nya." [Solo itself gives richly Javanese nuanced idioms. The traditional cultural heritage such as wayang, kethoprak, wayang orang and others constitute a source of ideas and energy that is inexhaustable.] Bambang Sadono. "Teater Gapit Memikul Citra Teater Jawa," Suara Merdeka, April 20, 1986.

12 "Hanya idiom-idiom falsafah hidup yang dimunculkan dengan perumpamaan jalan cerita wayang terasa berat. Harus diakui penonton yang hadir tak seluruhnya memiliki perangkatan pengetahuan soal wayang." [It is the philosophical idioms that appear throughout the course of the wayang tales which feel like a burden. It must be acknowledged (that) spectators who attend are not all knowledgeable about topics from shadow plays.] Hari D. Utomo, "Mereka Hanya Bisa Berteriak" [They can only scream] Kedaulatan Rakyat, November 24, 1990.

13 Communication with the playwright, July 24, 1993.

14 Ward Keeler, Javanese Shadow Plays, Javanese Selves (Princeton: Princeton University Press, 1986).

15 "Teater Gapit dari Solo, sekarang ini merupakan teater Jawa modern terbaik di dunia," Bambang Sadono, "Teater Gapit Memikul Citra Teater Jawa," Suara Pembaruan, April 20, 1986, p. 53. 
Jawa). ${ }^{16}$ Bambang Supranoto reviews the plays as owing much to traditional arts to the point where they "lift" elements from traditional forms, especially musical ones, without altering them in any way. "Complete with illustrations from tembang, gending-gending, soran, even kroncong, Rol performances clearly show a work lifted from the traditional Javanese arts." 17 The playwright, Bambang Widoyo, clearly acknowledges his debt to these musical sources. However he differs from his critics in his interpretation of their meaning, which critics assume is explicitly programmatic. One reviewer, Ardus Sawega, recommends this strategy of borrowing from traditional genres for other regional arts described as "subcultures" throughout the country. "Other subcultures: Aceh, Batak, Sunda, Nusa Tenggara, and so on, with creative spirit can [also] enrich and energize Indonesian culture. This can become a new ethic that erases the syndrome of Indonesianizing [regional arts]."18 Presumably regional troupes acting on this advice would not only borrow from traditional musical genres, but also script their dramas in regional languages. The combined force of provincial music and languages would then counter the homogenization of local cultures known as "Indonesianizing." Critics readily note that Widoyo scripts his plays in crude low Javanese (Jbahasa awa kasar) rather than in Indonesian, achieving a unique medium of "dramas" (spoken in) Javanese. ${ }^{19}$ Yet Widoyo himself acknowledges only his desire to write plays in Javanese, not serve as a model for other regional artists.

What is of interest here is the possibility that Indonesian critics such as Sawega equate "regional drama" with "new models" and judge them from a national perspective that inadvertently encourages the process of "Indonesianizing" these same critics wish to avoid. The irony that comparative review and standards for national theatre would promote more regional languages scripts and performances indicates the underlying tension in contemporary Indonesian dramatic genres: the popular audience for Gapit plays is only peripherally concerned with national culture and its potential models.

\section{New Javanese Theatre}

In these ways Gapit Theatre's stage performances define a new, linked national and cultural tradition by usurping prior Javanese musical and dramatic forms; ironically the result can be that the plays are used as an example of subordinating Javanese as one of many regional possibilities, thereby diluting the force of specific idioms in vernacular Javanese. At the same time Gapit theatre challenges those people who define it as a hybrid national art form because the performances resist easy conflation of "national" with "modern" arts. In both Rol (Role) and Tuk (Spring), the plots focus on the languishing appeal of live performances of wayang wong as symptomatic of the decline of traditional Javanese arts. Older characters speak regretfully about the passing of all forms of wayang as entertainment, even as they note with bitterness new forms of entertainment which provide no employment for the young: television shows, video recordings, films. The characters themselves generate nostalgia in national critics as the older Javanese way of life is abandoned for more cynical means of livelihood. "Salamun, a wayang-orang actor, becomes a pimp," writes Bambang Supranoto. "[From] these former wayang-orang actors: Kangjeng,

16 Tok Soewarto, "Gladi Teater Gapit: Buktikan Bahwa Sandiwara Jawa Tak Akan Mati Hari Esok?"[Gapit Theater proves that Javanese plays won't die out?] Pikiran Rakyat, March 28, 1985.

17 Bambang Supranoto, "Rolnya Teater Gapit Menyengat," n.d.

18 Ardus Sawega, "Realisme Sosial Gaya Solo," Kompas, December 3, 1989, p. 6.

19 "Menggunakan sepenuhnya medium bahasa Jawa produksi Teater Gapit yang kelima ini kian menemukan bentuk keseniannya yang paling tepat, drama [berbahasa] Jawa." Ardus Sawega, "Realisme Sosial Gaya Solo," Kompas, December 3, p. 6. 
Salamun, Mbok Jiah ... we can see clearly their role in responding to the demise [bobroknya] of the life of wayang-orang." 20

This troupe's references to traditional art forms are enhanced in the New Order era by the scripting in vernacular Javanese, so that the language itself recalls traditional wayang wong performances. Reviewers of Gapit Theatre often declare that modern entertainment is eclipsing regional arts; however they make their complaints in Indonesian. The point is made more subtly when the actors are speaking everyday Javanese. This is primarily due to the power of Javanese to convey linguistic puns and inside jokes. For example, the playwright employs a sharp wit in setting up dialogues between older characters, such as Lik Bismo in the play $T u k$, who is a former wayang kulit assistant who narrates the plot of Janaka, and Bibit, an unemployed young man who blames the problems of the neighborhood on the "big shots in Jakarta." 21 Except for a few rare loan words from English or Indonesian, the script has both characters expressing themselves in ordinary Javanese. As in the play, Rol, in which characters lament the lack of support for wayang-wong performances, the curses and humor in these exchanges lose their appeal if translated from Javanese into Indonesian. Spectators who view Gapit performances have told me that the pleasure of listening results from the use of Javanese. Ironically, it is only through speaking "low" Javanese that the actors insistently call attention to the loss of older genres and thereby establish their own performances as "new."

Although the Gapit troupe plays primarily to audiences in Solo at the Taman Budaya Jawa Tengah (Central Javanese Cultural Center), they have also performed in Jakarta at the Teatre Ismail Marzuki. While many Jakartans know Javanese, audiences enjoy the plays even when they are unfamiliar with the language spoken by the actors. Ardus Suwega writes in his review of performances of the play, Tuk, at the Indonesian Theater Festival in July 1993,

Even though the performance itself was rather difficult to follow for those who do not speak Javanese, the strength in form and in the dynamic character [of the drama] succeeds in keeping [our] attention. Borrowing from ketoprak, Gapit Theatre does new things with [its] themes. Without much difficulty the group appears to have gained its own identity. The result is [that] problems which always accompany the intermingling of tradition and local identity become a singular strength. ${ }^{22}$

Thus Gapit theatre enlivens national dramatic form through the force of Javanese as a regional language because, according to critics, it recalls older genres and retains the local language. 23

However Gapit theatre is also distinctive in the style and delivery of its actors, as well as the types of characters it engages and the everyday situations they portray. One critic compares Gandrik Theatre from Yogyakarta with Gapit Theatre performances, noting, "Whereas Gandrik has a slapstick style (sikap-konyol) full of witticisms (seloroh), Gapit emphasizes

\footnotetext{
20 Bambang Supranoto, "Rolnya Teatre Gapit Menyengat," n.d.

21 Alan Feinstein, "Modern Javanese Theatre," forthcoming.

22 Ardus Sawega, "Dua Kecenderungan Teater Baru" [Two Tendencies in New Theatre], Tempo, July 31, 1993. "Meskipun pertunjukan itu sendiri agak sulit diikuti oleh mereka yang tak berbahasa ibu Jawa, kekuatan bentuk dan inamanya yang dinamis berhasil menjaga kesadaran. Meminjam bentuk ketoprak, Teater Gapit melakukan pembaruan dalam tema. Dan terasa tampa beban grup ini tampil dengan identitas sendiri. Hasilnya, persoalan yang selalu menyertai ketengangan antara tradisi dan identitas lokal justru menjadi kekuatan utamanya."

23 Benedict Anderson, Language and Power: Essays on Political Culture in Indonesia (Ithaca: Cornell University Press, 1990).
} 
the tragedy of little folks, their naivete as they face modernization; . . they don't joke, what is witty are the twists of fate." 24 According to critics this technique of locating humor in everyday situations rather than in contrived plots makes Gapit Theatre appear particularly "Javanese." Tok Soewarto comments that "Bambang Widoyo is said to be skilled at bringing the lives of ordinary people close to him to the stage. He tells stories of Javanese society and everyday customs, including requests for blessings from the dead (as in the play, Leng [Anthill])." 25

Furthermore, according to the same critic, Leng succeeds as a play in innovating theatrical conventions precisely because it resembles modern films in the way it constructs narrative tension. "With filmlike techniques (tekhnis-filmis) his scripts are enticing." 26 Thus critical reviews seek to explain the appeal of Gapit Theatre by comparing it both to modern venues and forms of dramatic performance and applauding its use of stories of "everyday customs." The critic Syu'bah Asa has identified the innovation at work as a pleasure in parody attributed in part to the use of traditional music forms.

Leng has parodic readings which deliver a fresh jolt. Knowing the Central Javanese peoples so well, [the playwright's] humorous and spontaneous language is augmented by the rhythm of musical forms: gending and tembang [which] create a show that pleases one from the very beginning. That is the main distinction between Leng and [another play] Tik Tak Tok [another play by a different troupe] which is dry and boring. ${ }^{27}$

In the same review Syu'bah Asa cautions Gapit Theatre actors against losing their fresh appeal through "dramatic acting." "This is a group founded in 1981 who often tours in the rural areas. In setting, language and aura [bau], which are clearly Javanese, half of the actors have a tendency to 'dramatic acting' which they are aware of becoming conventional and which prevents them from simply daring to sit and speak Javanese; instead they bow and scrape as in provincial plays which imitate the Dutch." 28 Obviously the decision to script plays in Javanese remains the most noteworthy strength of the troupe only if it provides new venues for the actors to explore new stage techniques as well.

Gapit Theatre dramas are both attractive and commemorative because the contentstories of ordinary people's lives-and the exclusive use of the Javanese language insure that, "Javanese arts will not die out in the near future." ${ }^{29}$ Tok Soewarto's suggestion that the performing arts in a language spoken by nearly one hundred million people would be in danger of "dying out" may actually reflect an anxiety felt by middle-class Indonesians, many of them native speakers of Javanese, who perceive an implicit threat to regional lan-

24 "Gugatan Jawa Kasar" [Accusations in/of Crude Javanese], Kompas, July 1986.

25 Tok Soewarto, “Gladi Teater 'Gapit' Buktikan bahwa Sandiwara Jawa Tak Akan Mati Hari Esok?” Pikiran Rakyat, March 28, 1985.

26 Ibid. In Leng the scene opens on a factory which has been built near a pilgrimage site, a local saint's grave, Kyai Bakal. The noise provokes the curses of Bongkrek, a former factory foreman, who is now unemployed. Gradually the plot unfolds, alternating between scenes of forced displacement of nearby residents and scenes of conversations between the factory manager and his servant, Bedor. The play ends with a bomb threat and arson at the factory.

27 (". . . merupakan kejutan yang segar. Pengenalan lapisan rakyat Jawa Tengah pedalaman itu, dengan bahasa yang lugu dan spontan ditambah iringan gending dan tembang sudah menjadikan tontonan ini menyenangkan sejak pertama. Dan itulah beda terbesar dengan tik tok tok yang kering dan bikin capek.")

28 Syu'bah Asa, "Dua tentang Kenyataan Sosial," Tempo, July 12, 1986, p. 82.

29 Tok Soewarto, "Gladi Teater 'Gapit' Buktikan Bahwa Sandiwara Jawa Tak Akan Mati Hari Esok?" Pikiran Rakyat, March 28, 1985. 
guages (their own included) as the designated national language permeates modern institutional settings: schools, workplaces, the market and the media. This anxiety may account for audience interest in Widoyo's nostalgic dramas. "Gapit is consistently struggling in a creative way with new forms of expression; it is drama (modern theatre) that speaks Javanese unlike Javanese literature ... [which] Arsendo Atmowiloto has declared 'dead,'" writes Ardus Suwega. ${ }^{30}$ Encountering Indonesian as the primary language in the workplace, in their children's schools, and in the mass media of television and recorded music, urban Javanese speakers must fear that the disappearance of their language from public contemporary life may ultimately lead to the disappearance, appropriation, or radical transformation of Javanese performing arts. Since those arts are often predicated upon narrative performance in Javanese, Gapit performances become all the more poignant and confrontational in the rude comments and hilarious dialogue of their unassuming characters. Yet despite the rude, defiant energies of Gapit and its portrayals of social conflict between the less powerful (wong cilik) and the elite, none of Gapit performances have been censored, and we could ask what has made these portrayals of everyday hardships of many Javanese urban residents less threatening than others which have been banned in print or dramatic form. Censors forgive and audiences enjoy Gapit theatre. Why? It appears that the significance and appeal of Gapit theatre can be located both in its reclamation of a regional language and in its citation of earlier popular genres-wayang wong, ketoprak, ludruk-even as the performances call attention to the perceived demise of these performances as a way of life.

\section{Gapit Theatre: Theatrical and Political Stances}

Gapit Theater is relatively recent in origin and seeks to maintain a small but closely-knit core of actors it its troupe year after year. ${ }^{31}$ It is named for the small swinging door cut in the larger gate entrances to the Solonese courtyard, Baluwarti grounds, through which residents entered and left the compound of the sultan. Formed in 1981, the troupe membership has been remarkably stable for the last thirteen years, with many of the actors performing in successive plays year after year; most of the actors have been students from the Surakarta Arts Academy. Widoyo's older brother, Mas Lis Suliyanto, has been the producer of Gapit Theatre since it's inception, and under his guidance, Gapit Theatre has performed seven of Widoyo's plays to date. The troupe has garnered widespread respect in Indonesia; journalists who gathered to review the 1993 national arts festival acknowledged only two troupes, Gapit and Gandrik, as "exceptional." Gapit Theatre together with the Yogyakarta-based troupe, Gandrik Theatre, were distinguished by Tempo reviews as "senior" because they had accomplished much with innovative styles in a broader national scene. Such praise by Indonesian critics is rare, though in this case well-deserved.

Gapit Theatre's first major performance was in 1983, with the staging of Widoyo's play, Rol, at the National Press Monument in Solo. Hailed as a "breath of fresh air into Surakartan theatre," ROL was received well by audiences and by the press. ${ }^{32}$ The script explicitly depicted the operation to purge criminals (pemberantasan kejahatan) in 1983 and 1984. Rol weaves between two thematic worlds, that of Indonesian film production and the underworld of politics in the 1980s, as characters narrate their lives as a small group of wayang-

\footnotetext{
30 Ardus Suwega, "Menghapus Sindrom 'Mengindonesia'," Kompas, March 31, 1985.

31 Several actors have been with the troupe since its inception, most notably Mbak Yuyun WS, Pak Pelog Sutrisno, and Pak Bangun Santosa.

32 Bram Setiadi, "Infus Bagi Kehidupan Teater di Surakarta" [Infusion for the Theatre Life of Surakarta], Surya Karya, November 18, 1983.
} 
orang actors rhapsodizing on the apparent demise of wayang as an art form source of employment. Two of the characters have come to depend on the mass media entertainments which displaced wawang and ruined their careers as actors, since they have adopted the "hobbies" of watching videos, films, and TV. The madman, Mukiyo, who shouts out the obvious, often speaks bluntly about these and other evasions. For spectators in audiences from Solo, this character is familiar since he is based on a well-known local figure who visits the foodstalls near the Solonese court gates. ${ }^{33}$

Widoyo's script for Rol focuses not so much on the decline of the traditional art forms themselves, but on the poor attendance of audiences at performances of traditional urban theatre due to the popularity of films and television. However critics rarely distinguish between the two phenomena-the death of an art form and the diminishment of its audience-preferring instead to make pessimistic judgements about the future of traditional popular culture. Ardus Sawega described Rol in a review in Kompas as "Javanese infused with Indonesian Breath . . . a social commentary through wayang-orang, a form of popular culture heading for bankruptcy." In many ways Rol has been prophetic; at the Indonesian National Festival in 1993 attendance at wayang wong performances was sparse compared to that at the dramas. Rol's debut in 1983 also coincided with the short-lived rise of the Indonesian film industry, which in the same year celebrated its first annual film festival. At the beginning of that decade Indonesian-produced films seemed to be burgeoning, ready to serve a large domestic market of young viewers. However by the early 1990s the production of Indonesian films had declined, giving way to international competition from imported Indian and American films. ${ }^{34}$ It remains to be seen whether Indonesian film directors will imitate Gapit Theatre's ironic stance towards their own aesthetic productions, presenting dramas that half-mock, half-warn the audience that local arts are shrinking in patronage and appeal due to a barrage of new forms of entertainment.

Rol scripted dialogue plays on a doubled sense of "roles" as theatrical and political stances. As Widoyo explains it, "roles" refer to both arts and politics; political roles are played off-stage by ordinary people experiencing unexpected terrors. These are discussed by the characters in Rol as they confront the mysterious killings which had just become an isyu, a hot topic, in 1983. The murdered corpses of gali-gali, petty criminals and tough guys, were being dumped in the streets of cities and towns throughout Central and East Java. At the debut performance of $\mathrm{Rol}$ at the National Press Building in Solo, mysterious killings were not simply a topic of discourse within the play. ${ }^{35}$ The building manager, who read the script only one day prior to performance, was particularly nervous when he learned the contents of the play. Widoyo later heard the reason: the building housed a temporary apartment upstairs which was used by those involved in the gali-gali disappearances. "However nothing happened," he said of the coincidence.

A subsequent play, Leng, focused most directly upon the plight of kampung, local neighborhood residents. Produced in 1985 and performed at various cities in Central Java throughout 1986, Leng's enthusiastic reception reinforced the critics' judgement that Widoyo had engaged his audience by drawing attention to local people's marginal conditions and livelihoods. By the time a fifth play, Tuk, was reviewed in 1989, both Gapit Theatre and Bambang Widoyo were well-known for distinctive subject matter and exclusive use of

\footnotetext{
33 Bambang Supranoto, "Rolnya Teater Gapit Menyengat," n.d.

34 "FFI, Beban Politik, dan Selera Publik," Tempo, January 8, 1994, pp. 98-99.

35 Waluyo Hadi, "Rol, Wayang Orang, dan Penembak Mysterius" (Rol, Wayang Orang and the mysterious killings], Kartika [Semarang], April 16, 1986.
} 
Javanese in scripts. Two other scripts, Reh (Power) and Dom (Needle) were produced to lesser aclaim in 1988, and 1990 respectively. Widoyo himself describes them as "imperfect" (belum sempurna).

While critics speculate on the motivations that prompt this playwright to write exclusively in Javanese and to focus his plays on kampung residents, a closer examination of his personal history shows that Widoyo's rebellious innovations have not sprung purely from a revolutionary spirit; early in his career, the playwright was sustained and even inspired by a powerful international institution. Widoyo began writing plays in 1982 when UNICEF invited him to create a script elaborating on the role of the handicapped in society. "I wrote [the first script] not only to highlight the role of the handicapped, but in a way to show how we all have handicaps of a sort," he comments. He adds that he felt no pressure to create a particular "viewpoint" to please his sponsor. The script of Brug (Bridge) unfolds a surreal story of conversations among a group of young people on a tour; they approach a bridge near dusk, and must decide how to return home. Composed in Javanese and performed for village audiences, Brug was also previewed by UNICEF officers, Victor Soler-Sala and Mr. $M$ Rajan, in the subdistrict of Colomadu. The officers commented that the children in the audience ". . . became so involved in the play as to help one of the actors look for a missing package." 36 Their experience introduces a topic that will be treated later in this essay: Widoyo's plays often blur the conventional borders that separate the audience from the stage.

\section{The Language of the Stage}

It was through this first project, Widoyo says, that he discovered "the language of the stage" (bahasa panggung). Prior to writing plays, Widoyo had composed short stories which were published as serial episodes in the teen magazine, Hai, from 1976-77. A later series entitled "Saraswati" was published in 1980. He also enrolled in the Indonesian Academy for Performing Arts, Surakarta in 1980, where he studied gamelan for seven semesters. The influence of Javanese gamelan, along with the tembang sung by his mother and the recurring imagery of wayang-wong characters, inspired him to interpose traditional arts into contemporary theatre, an action he readily acknowledges. Critics most frequently claim that Widoyo's plays draw upon the popular form of ketoprak in their staging and dialogue, and in some way Widoyo's scripts refer to all these traditions, but at last their debt to prior forms is secondary. One would never call these plays derivative. Their most important accomplishment is to synthesize and highlight Javanese verbal arts and ribald humor in ways which become accessible both to the national art community and to local audiences. Making use of "low" Javanese and also the curses characters frequently hurl at one another, these plays manage to impress very different audiences as either artful or earthy and enjoyable.

"I still feel closest to Javanese (kami masih akrab dengan bahasa Jawa)" Kenthut has told many reporters and merasa critics. Not only the vivid imagery of his titles, but the bold and scandalous speech of his characters entertains audiences and reviewers alike. "In the speech of the three central characters of Leng: a cemetery guard, a masseuse, and a fired factory manager, curses (pisuhan) as well as jokes spice up their speech and enliven the play. Bongkrek is counseled to keep quiet, instead he curses.... The businessman is also not free from

36 Victor Soler-Sola, "A Glass of Tea for Development," New Forum 11 (1981). 
curses, which he hurls at Bedor, his loyal servant." 37 Tok Soewarto writes, ". . the jargon peculiar to the scripts ignites the drama with curses which cannot be disguised in words such as idiot, scoundrel or bastard." 38 Some critics complain that the vocabulary distracts from the drama, but they are in the minority. Judging from informal discussions and my own observation of performances in 1986 and again in 1993, most audiences take delight in the speed and precision with which characters verbally lambast one another and their surroundings.

As I tape-recorded the performance of Tuk at the National Theatre Festival, the young man seated behind me often shrieked with laughter at jokes and curses alike and often spoke loudly to the characters on stage. Either he repeated their phrases or explained things to them, giving commentaries on situations the characters themselves did not appear to understand. "Idiot!" he would say loudly, "Idiot!" "Where's the chicken!?," he would shout. "In the well!" he would answer. ${ }^{39}$

Some reviewers see Widoyo's use of Javanese as an appropriate response to counter national language hegemony. The choice of regional language as an artistic medium is "proper" (sah) one journalist concludes, since Indonesian is subtly influencing Javanese through a process which he calls "Indonesianizing," a process that ultimately redefines Javanese as the language of a subculture. ${ }^{40}$ The force of curses can counter this process, since the scripts state in explicit terms what would otherwise be sanitized or tamed by euphemisms in national discourse. By cursing dramatic characters signal a defiance to events regardless of the narrative outcome. It is not to say that curses escape the influence of "Indonesianizing" Javanese, but they do provide an undeniable pleasure for actors and audiences alike, and it is a pleasure which cannot be translated easily into Indonesian.

The other memorable aspect of Gapit theatre is live gamelan performance; it is difficult to imagine one of Widoyo's plays performed without full gamelan orchestral accompaniment. Although Widoyo denies his reliance on the traditional arts-" I'm quite removed from tradition," he told one reporter-he is nevertheless committed to gamelan as an integral part of his dramas. In the same review he assures the reporter that his use of Javanese in the script "... does not mean he is allergic to the national language." 41

One can better appreciate the artist's choice of music and language after learning of the experiences which led him to write dramatic scripts. In his biographical statement for Gapit Theatre, Kenthut says "my Javanese can convey (mewadahi) the aspirations of theatre." 42 Those aspirations do not appear limited to the stage crowd and audience. "I write about kampung people because I'm close to them, I'm from such a kampung. Their strength lies in their living so close, what they know about each other."

\footnotetext{
37 Tok Soewarto, "Gladi Theatre 'Gapit' Buktikan Bahwa Sandiwara Jawa Tak Akan Mati Hari Esok?" Pikiran Rakyat, March 28, 1985.

38 Ibid.

${ }^{39}$ Siegel has noted the degree to which Surakartan audiences for Sri Mulat performances in the 1980s frequently exclaim and comment on the stage action, responding as much to the linguistic or sensory shock of hearing certain words or sounds as to the narrative plot, James Siegel, Solo in the New Order: Language and Hierarchy in an Indonesian City (Princeton: Princeton University Press, 1986).

40 Argus Suwega, "Bahasa Java dengan Napas Indonesia," Kompas, November 9, 1983, p. 6.

41 Ardus Suwega, "Realisme Sosial Gaya Solo," Kompas, December 3, 1989, p. 6.

42 Putut Pranama, "Interview of Bambang Widoyo," Dar. Mnd. (n.d.) "Profil: Sebuah Glas Teh untuk Pembangunan."
} 


\section{Personal Background of the Playwright}

To place such statements in context, I interviewed Bambang Widoyo on July 23 and 25, 1993 and asked him to discuss his scripts and the ways they contribute to Javanese arts as traditional forms of performance. ${ }^{43} \mathrm{His}$ responses suggest that the special tone of his plays results from his efforts to depict contemporary situations as they relate to earlier historical conditions and eras, particularly the experiences of his own family during the Revolution era (1942-1949).

We began the first interview one afternoon in one of the practice buildings on the grounds of the Cultural Center on the northeast side of Surakarta. It was a typically hot afternoon, and the building had a languid, deserted air as most festival participants sat in the shade and chatted, or napped in the main pavilion. Near us local children were playing and making noise among the instruments; a goat was calmly grazing in the tall weeds to the side of the pavilion. Widoyo said little until I asked him about the sparse analyses of Gapit Theatre written by Indonesian scholars; in two collected essays on Javanese literary arts there is only passing mention to the plays of Bambang Widoyo S.P. and I asked him why. ${ }^{\mathbf{4 4}}$ Widoyo explained, "If we speak of Javanese plays in the Javanese language, there were actually many in the 1960 s, but they were on radio. On stage [though] rarely, perhaps only on the seventeenth of August celebrations. There hasn't been much in the way of stage arts [in Javanese]." 45

Because so many commentators had focused on the subject matter of his plays, I asked him why he writes mostly about urban neighborhoods and their residents. He replied, "Kampung people are marginal, ... and as it happens, they are the people to whom I'm closest, because I'm from a kampung myself." 46

Particularly significant to the artist were events in his mother's life which remained memorable to him. Widoyo described his mother as "the source of my stories." Both his mother and his grandmother were vivid storytellers at home (mereka pinter ndongeng); several of Widoyo's plays include lyrical songs, tembang, which he remembers his mother singing at home when he was small. Just as his mother sang to him and told him stories, so he draws on those memories for many of his scenes where characters face intolerable hardships with displays of wry humor.

\footnotetext{
43 I would like to thank Tinuk Yampolsky, who introduced me to Bambang Widoyo in Solo in 1993, and who encouraged me to interview him about his plays. Tinuk and I also met with Widoyo and his brother, Lis, at their home the following week, when I was able to ask the playwright to clarify some of the points in this interview. He generously offered copies of the news clippings and scripts on which much of this article is based. The translations to English are my own.

44 Setya Yuwana Sudikan, "Sastra Jawa Modern, Sastra Pinggiran," Keterlibatan Sosial Sastra Jawa Modern, ed. Poer Adhie Prawoto (Solo: P.T. Tri Tunggal Tata Fajar, 1991), pp. 85-92. Also, Kuntowijoyo, "Sastra Priyayi Sebagai Sebuah Jenis Sastra Jawa," Ketertlibatan Sosial Sastra Jawa Modern, ed. Poer Adhie Prawoto (Solo: P.T. Tri Tunggal Tata Fajar, 1991) pp. 51-59; and Suripan Sadi Hutomo, "Drama Dalam Sastra Jawa Modern," in Wawasan Sastra Jawa Modern, ed. Poer Adhie Prawoto (Bandung: Angkasa, 1993), pp. 59-66.

45 Interview with Bambang Widoyo, July 23, 1993 at Taman Budaya Jawa, Surakarta. "Kalau sandiwara bahasa Jawa itu, sebetulnya dalam tahun enam puluhan masih ada, tapi dari radio, dalam radio. Tapi dalam panggung ya bentuk panggung, memang jarang. Ada ya mungkin perayaan perayan tujuhbelasan. Jadi untuk duluan, Ya dulu untuk kesenian panggung itu rasanya, ngak begitu banyak."

46 [Kenapa tertarik kepada sandiwara tentang orang kampung?] "Orang kampung orang pinggiran orang ... kebetulan memang itu, jadi saya memang lewat itu lewat orang kampung, yang kebetulan memang saya sendiri akrab dan saya sendiri memang orang kampung."
} 
Widoyo was generous with stories of his life. What follows is the summary of a brief autobiographical sketch which he offered as background to his scripts.

\section{Biographical Sketch and Some Stories}

Bambang Widoyo, S.P. was born in 1957 in Solo, Central Java, the youngest of nine children. Both his parents were from Solo, "distantly noble" (agak ndoro), and because they were very poor, he describes his own birth as "a bit of an extravagance (pemborosan)." His mother's mother had connections to minor aristocrats in the court (ndoro), but his own mother was orphaned at the age of eleven and after that lived with various relatives, grandparents and an older aunt. "Many of these relatives had official positions, and they were able to arrange a fairly good marriage for the young orphan. She spent much of her life insuring that her children would not experience the hardships that she had suffered."

"During the war years [1942-1949] my mother was forced to return to her husband's village, since the city had no markets or food supplies during the Occupation; most of the food had been taken by the Japanese soldiers. When the Japanese arrived, she was forced to return to the village. My father worked intermittently as a barber.

"At Independence, my mother did not feel at home in the village as it had much gambling and was a poor environment in which to raise children. Her husband, who enjoyed staying with his own parents, did not wish to return to the city, (probably he was spoiled by his family)," Widoyo laughed, "but my mother was determined (nekad). She stayed with distant relatives in Kalenwanto selling snacks as a street seller to feed her children. She had not brought all of her children to the city, but left three in the village. She had only two of them with her."

One story which he remembers vividly describes the event which impelled his mother to return to the city during the Revolution.

"There was a baby, still nursing and shitting in his pants, still really small. At that time, mother was not given much respect in the household, because she was living with relatives. She felt, as someone living in someone else's house, that she had no choice but to swallow her pride there. Father was unemployed, because the village did not have a barber and even if they did, villagers rarely went for a shave, and as for the cost of the shave, they hardly ever paid.

"Father was spoiled by his parents. He was the eldest. My grandparents happened to be well-off, they had a lot of dry garden land. They favored their own children, even in distributing the food, they set different portions of food for their children, son/daughter-inlaw, and grandchildren. This went on for several years, during the war and during the uprising in Madiun. Mother had to move two times to different villages. One day, she was left with only one piece of batik to wear. Early one morning, the baby soiled her only batik, and she wanted to wash it since it was still quite early (subuh). She went to wash it and took a bath at the same time. She hung the cloth up by the well, and bathed nearby. When she returned, the cloth was gone. It was stolen by a dog (digondol) because it was covered with shit, and the dog began to eat it. When she found it, it was torn up and when she sewed it together, there was only half a piece left.

"That was the final straw. It made her want to move to Solo right away. All those years, and to be left suddenly with only half a piece of cloth, it was the last straw. She stole some chicken eggs from my grandparents' farm and sold them to get some pocket money (sangu) so she could move to the city. She didn't even mention it to my father. Because of this she 
never wanted her children to come to such a point. Probably they fought, but she never told me about that. She told me the story, how she returned to the city, followed relatives.

"My mother worked at many odd jobs in the city. Fortunately she could sew mattresses. She had taken courses, eh, gone to school, a kind of girls' school but never finished it. While she was living with relatives everywhere, she would sell stuff. That was her way. She was determined. She would walk seventeen kilometers to the village. One time, maybe it was during the Communist uprising in Madiun, I don't remember exactly what year, it was wartime (1948). Market stalls still existed along the side of the road. She was walking with two kids and pregnant as well. She managed to succeed, sewing clothes, mattresses, until she had enough to get by fairly well.

"So then Father started coming around to see how she was doing. He followed her, probably because he missed her. When he saw she was doing well, he didn't stay, just hung around, probably because he was embarassed. He didn't dare move in with her yet. Now she still had three children in the village, and this was a constant burden to her. She had the ability to save a little, because she thought her children would need clothes, need to be visited and comforted. There wasn't very good transportation to the village, just horsedrawn carriages. One day she was really missing them, especially the third, who was rather weak physically. She didn't favor any of her children, but because this one was so small, and she'd had to leave them in the village, she decided to visit them, just to comfort and give them encouragement, and then return to the city.

"She had taken Mas Lis along with her, he was still small, and a younger sister. They had to be left at home alone while she worked and returned to the village; the neighbors at Margasari took care of them. Since it was already early afternoon as she set out, there wasn't much transport. She could only take the horsecart eleven kilometers, and then sunset came on. The roads were still dangerous, as the uprising was still going on, so criminal elements were out. She had wanted to visit her children, but here she was, afraid. It was dusk, almost night, and she was a woman, with a small child, Indah [an older sister].

"In the middle of the road she hesitated, deciding whether or not to continue or to return. Maybe she prayed, I don't know. She met a child whose physical condition was like the one in the village she was trying to reach. The child approached her and wanted to come along. Mother was surprised, wondering whose child was this? No parents, no one to look after this child, who was about eleven years old. 'I'm going home, my relatives are in the village,' the child said, 'I want to go to my older sister's house in the village.' Coincidently my family knew those people. Mother felt she had found a companion in this child, even though she was only nine, maybe eleven years old. She said she wanted to go to Sukahardjo, the village before theirs. But when they reached it, the child didn't stop to visit her sister's and said she wanted to come with Mother. Mother felt as if she had found a close friend, even with such a small child, but she felt so calm and safe with her. So when they reached home, and offered the child some food, she just ... disappeared. Not like they couldn't tell which direction she had gone, more like a mysterious disappearance (hilangmisterius). That child must have been a temporary companion for the road."

\section{Historical Hauntings}

Such tales of hardship and the ghost story above resemble those told by the older characters who deliver long monologues while standing in a single spotlight in Widoyo's plays. In the play, Tuk, for example, Mbah Kawit speaks half to Lik Bismo and Bibit, half to herself about the memories shaping her determination to stay in the urban compound until she 
dies. Staging for these scenes is minimal and allows for maximum improvisation with lighting and props, which some critics feel is a strength. Others contend that little inventive improvisation actually goes on, and that the absence of detailed staging directions leads to boring or repetitious blocking, weakening the performances overall, since ". . the light system is frequently empty, aimed more to provide illumination than clarity. ..." It should be noted that when Widoyo's characters are lit by a single light, they recall wayang wong characters, who were also illuminated simply. ${ }^{47}$

The power of these characteristic monologues lies in the local knowledge and particular experiences characters relate as they address the audience about ordinary events that took place during extraordinary times. Characters in the play, Tuk, satirize or recall common explanations for the historical relationships underlying events such as the displacement of their neighborhood. Lik Bismo counsels Mbah Kawit to accept the arbitrary decision of those who own the compound because they are "like those before them"; similarly, in the play Leng, the older characters, Pak Kanjeng and his wife, counsel the young rebel, Bongkrek, to stop shouting at the factory and to accept construction of the industrial park planned to surround the pilgrimage tomb.

In the same play, a character named Bedor, assistant to the factory manager, adopts the role of the servant-clown in the wayang tradition, for he often talks to himself in exaggerated dueling voices as if he were addressing his employer, Juragan, and then staging his responses. The employer, who is haunted by visions of imaginary crowds outside his factory, repeatedly commands Bedor to look off stage and verify his hallucinations. Bedor responds in soothing and cajoling tones, echoing the servant-clowns who address elite warriors with similar advice and comic role-playing in lakon.

Bedor: "Easy! It's all taken care of sir! Haven't you given donations? Just put together a bucket of loose change. ..." [He yells, standing near the door]: "Hey folks! Here it is! My winnings are divided fairly pyyrrr. ... "[He runs his hands through the coins] "Hey, don't push, no need for a free-for-all, be orderly, hey! Don't ring the bell so much! Remember your friends . . . pyrr ... its settled, it's all taken care of, Sir."

Bedor, whose name has been borrowed from the figure on a set of Chinese playing cards, plays on the role of servant by humoring his employer while he is awake and then mocking him while the Juragan sleeps. Bedor declares at one point, "Such a waste, he didn't drink his medicine. It was so expensive, I might as well finish it off for him." Bedor's actions and asides to the audience evoke neither the intimacy of the servant/clowns with their noble princes nor the cynical humor portrayed by servants in the contemporary bourgeois households where the action takes place in ketoprak and ludruk dramas. Bedor displays a curious amalgam of qualities borrowed from servants in both dramatic traditions, yet he's rougher and more distant; he lacks their familiarity with and loyalty to their superiors.

This gentle and not-so-gentle parody shapes many of the Gapit plays as characters reminisce about particular dramatic performances, particularly wayang wong performances, and lament that they are no longer patronized as they once were in Java, even as they caricature aspects of those performances on stage. Although the characters rarely aspire to recreate the lakon except in nostalgic passages or parody, the remnants of those well-known tales are easily discerned by audiences as citations of the wayang tradition. Lik Bismo gets lost in old

\footnotetext{
47"Penataan lampu juga seringkali pengaliami kekosongan karena light system lebih diarahkan untuk penyinaran dari pada untuk penerangan." Hadi Waluyo, "Rol, Wayang Orang, dan Penemabak Misterius," Kartika, April 16, 1986.
} 
battles with Senkuni; he waves the puppets as he rages at them and ultimately puts them away to give Mbah Kawit advice. The fragments of the tale hang like scraps on the clothesline strung across the stage. By citing only glimpses of their imagery, Gapit scripts remind us of traditions that are passing.

\section{Blurring the Boundaries of the Stage}

Widoyo is well aware that Gapit performances blur the boundaries that usually divide the audience from the action on stage, and he takes some pleasure in producing this effect in his plays. Sets resemble the backyards of urban neighborhoods complete with leaking buckets, broken stools, and empty chicken coops. Such ordinary staging grants actors, many of whom are from such neighborhoods themselves, a freedom to enter the stage from the audience, as if returning from market or even enter the threatre on bicycles, like street-sellers, as they do in the first scene of Tuk. In one performance of Tuk the playwright invited his own neighbors from the compound adjacent to the Mangkanegara to see the play which portrayed the Magersari, a compound dependent on the good will of its aristocratic landlord. Having received no forewarning that many of their own idiosyncratic expressions had been fitted into the script, the neighbors sat with amazement through the show.

Widoyo sees this close interaction between actors and spectators as an integral part of the appeal of Gapit performances, for it draws from the personal experiences of the actors as well as the audiences to intensify their personal encounter with dramatic forms. Widoyo recalled, "I didn't let them know what was going to happen beforehand. The first performance was for theater people, that is, those who have a kind of appreciation of the theater world. The first time, they see it, they may not know or may not want to know about the lives of kampung people, even though it may be their everyday experience (for actually many theater people are from kampung themselves). So when they see the performance they may feel surprised, not surprised really, more like [they say] "Hey!" It's a kind of portrait of themselves that flashes by. But they're familiar with the idioms I use since they're drawn from what they say every day. That's not something that they take away from the performance, even though they know and experience it."

When asked about occasions when people from a kampung see the plays, Widoyo answered, "One performance, one friend of mine brought a woman from the market, because my friend, his wife was a seller. So he invited a few sellers (bakul) to come and watch. Wow did they ever get the point of the play. They felt as if they were represented on stage while they talked; when the characters spoke, they felt it was one of their own."

Reflecting on this process of eliciting audience response, Widoyo went on to talk about his own motivations for experimenting with the spectacle of theatre performance. He described at length the time when he transported his own neighbors to a performance of Tuk. "Once I wanted to shift my focus. The third night of performance, I got the folks behind my house to come see the play. But I didn't tell them anything beforehand. I didn't ever talk about it. So I got a bus to bring all my neighbors. They were a little surprised when they saw the sets. There was a well, these small shacks, it was as if they had reentered their own homes. So when the performance began and the characters began to come on stage, [they saw that] a few of them were from the neighborhood; since I had drawn the characters from neighbors. The tailor, the guy with the chicken, the market seller." What about the old woman in Tuk, Mbah Kawit? "The old woman was a composite character [campuran dari beberapa karacter]." 
"When the performance began, certain phrases of theirs were right in the play. They all laughed and enjoyed it. Even after it ended, for two months after, it was the talk of the neighborhood. It was as if the play continued, since it was based on their conversations at their own communal well. I often went and hung out there, listening to whatever was mentioned. So when they saw the play and it ended, their commentary went on and on. For two months, they continued to use phrases from the play. It was like a peanut gallery [literally, 'the verdict from the bikeshop,' hukume wong tumbal ban]."

I mentioned that it seemed as if the street language, especially the curses, were the playwright's own kind of academic language, as the critic, Tinuk Yampolsky, once said. Widoyo responded, "Abusive language can be a strength [kekuatan]. It's stage language, not literary language. It's a force that's difficult to replace. For example in the play, Tuk, there are several times ' $a s u$ ' is thrown around, but the meaning is entirely different. Mas Lis says 'Sonofabitch! [Asu!]' cursing the well; Lik Bismo curses Senkuni, a character in wayang, because he deeply resents Senkuni. From one word ' $a s u^{\prime}$ ', there are different senses; the quality of the abuse also differs. . . . People feel offended (risi) when they watch Gapit. Some take offense at the cursing." Widoyo ultimately trusts his audiences to judge the forceful language for themselves. "I really respect and value the audience ... they can take whatever they want from my plays; they can just take the jokes, or just the curses, if they want, it's no problem."

The language Widoyo uses certainly introduces verbal sparring and play with words in "low" Javanese. In keeping with the speech of the urban neighborhood in which he lives, Widoyo's scripted dialogues explode with colorful abuse and banter, which often invites more philosophical responses from older characters. Although his plays could hardly be described as didactic, some characters do aspire to give advice to the others, said the playwright. The relationships between cursing, angry young characters and weathered, more patient older characters are key to many of the dramas.

The function of each individual character is often indicated by a distinctive, metaphorical name. One young man, clearly past high school but without a job, is called Bibit, or "seed," connoting especially one that hasn't sprouted. Said Widoyo, "I wanted a character with a sense of potential, like a seed which hasn't been planted properly, or watered. Actually there is a connection between the well [for which the play is named] and a guy named Bibit." Bibit is a jokester who teases each of his neighbors in Margasari: the errant tailor who cheats on his wife, his wife who berates him in hilarious and lethal expletives, the market seller who isn't very successful, but still dreams of her future stall, the owner of a fighting cock that meets an untimely demise in the well. Each character in turn is prodded verbally by Bibit, who alternately mocks and helps them as they feud with each other, cursing their bad luck throughout the day.

Widoyo explained, "All of these characters are cornered and hindered in their attempts to get ahead [terpojok, terbatah di jalan]: the seller who never really succeeds, although in the kampung terms, she makes it, but in terms of what happens in the real market, who owns the market? .. . She may make a profit, but she doesn't know who she really benefits. ... The important thing is that she sells things, even though she gets the leftovers; but the real market and its conditions, she never really knows."

Despite the arbitrary obstacles in their lives, characters nevertheless draw strength from each other and from unseen influences. Throughout the play, Tuk, the character of Mbah Kawit, who is a composite figure of an elderly, destitute woman, is terrified that the neighborhood will be demolished or its residents evicted. In one interlude between scenes she 
sings a tembang in response to the rumors that the complex of rental units where she lives will be sold soon. The tembang is one Widoyo's mother sang during the revolutionary period to ward off the threat of invading troups.

\section{Ni grigit kaki grigit \\ aja mangan balung kulit \\ mangan padhas watu \\ alas padhang pangonanmu \\ yatalah ya hualah yotalah ya hualah.}

Don't eat bone and skin

just stay in

your place in the forest

if black magic comes your way

it won't harm you.

Widoyo commented, "Tembang is really the source of Javanese artistic richness . . from the perspective of musical arts, the theme is established in tembang. From stage performance perspectives in ketoprak, there is also a focus on tembang. It is an internal strength to Javanese arts," he explained. "For example the one that is sung by Lik Bismo. That one, I got that from my mother, it's very familiar. And the one that is sung by Mbah Kawit, that's also from my mother, who got it from those around her. At that time, the Japanese had taken over and at night they would often loot the surrounding settlements. When families were afraid, to insure their safety at night during the looting, they would communicate with the one above (kommunikasi dengan yang di atas). So I used those tembang in the script. Because those circumstances reflect Mbah Kawit's situation. She's terrorized by the landlord of Magersari and by Sulieman. Her situation is similar to the moment when my mother had to stay inside the house with nothing to do, when the Japanese were looting."

\section{Conclusion}

Viewing Gapit performances and Widoyo's scripts in light of his commentary above, it becomes clear that his decision to write plays in Javanese not only recontextualizes traditions of wayang-wong, bringing them forward as contributions to modern drama, but it also links memories of historic events with knowledge of current conditions for urban neighborhood residents. These links between past and present inspire the narrative as well as the tonality of the plays. By experimenting with the boundaries of stage performance and audience response, Widoyo shifts attention away from cerebral interpretations of the narrative and toward engagement of local spectators who take pleasure in the familiarity of the set and the explosions of strong language that both disrupt and enliven the dramatic dialogue.

To the extent that Gapit Theatre cites wayang-wong in form and content, it also provides a commentary on this traditional art, for the plays invert the order and significance of the performance. Whereas wayang-wong relies on long stretches of refined conversation between mythic kings and warriors, interrupted gently by hypnotic song interludes and short bursts of comic parody, Widoyo's plays give the stage to the little people and their explosive curses. In this rougher neighborhood where warrior characters are absent, parody reigns. Most significantly Widoyo discovers the "language of the stage" in Javanese, such that the force of his mother tongue moves audiences to delight not just in occasional moments of comic relief, but in a continuous vernacular commentary that comprises the play. Whether or not spectators understand Javanese, they are drawn to this familiar theatre of everyday 
life through the endless rounds of petty quarrels and hardships, the cursing and "local wisdom of the bike repair shops." As Indonesians continue to suffer arbitrary limits on public expression in press and publications, it is worth remembering what can be said and heard in "the language of the stage" and what sort of enjoyment viewers derive from hearing a character like Bongkrek hurl words of abuse at the noisy factory, rather than "just stay silent" as he is counseled to do. 